Case Series

\title{
Sustained viral remission with directly acting antivirals in the treatment of chronic hepatitis $C$ among adolescent (12-17 years) survivors of childhood leukemia
}

\author{
Prasanth Kunjan Nadar Sobhan ${ }^{1 *}$, Bindu Sarojam ${ }^{2}$
}

\begin{abstract}
${ }^{1}$ Department of Gastroenterology, Government Medical College, Thiruvananthapuram, Kerala, India
${ }^{2}$ Department of Pediatrics, Government Medical College, Thiruvananthapuram, Kerala, India
\end{abstract}

Received: 15 August 2021

Revised: 11 September 2021

Accepted: 14 September 2021

\author{
*Correspondence: \\ Dr. Prasanth Kunjan Nadar Sobhan, \\ E-mail: drprasanthksobhan@gmail.com
}

Copyright: () the author(s), publisher and licensee Medip Academy. This is an open-access article distributed under the terms of the Creative Commons Attribution Non-Commercial License, which permits unrestricted non-commercial use, distribution, and reproduction in any medium, provided the original work is properly cited.

\begin{abstract}
Studies from India highlight the high prevalence of hepatitis C (6-25\%) infection in survivors of childhood cancers. Recently Directly acting antivirals (DAA) have been approved for treatment of Chronic hepatitis C (CHC) in children $>12$ years of age. Even though there are reports of efficacy and safety of DAAs in the treatment of CHC in hematologic disorders like thalassemia, there is minimal data on the efficacy of DAA in the management of chronic hepatitis C among adolescent survivors of childhood leukaemia. We performed this retrospective analysis to study Sustained viral remission (SVR) with DAA in the treatment of CHC among adolescent (12-17 years) survivors of childhood leukemia. This study also aimed to analyze the genotypic profile of hepatitis $C$ virus and adverse effects of the DAA in this group of adolescents (12-17 years). 5 adolescents (12-17 years) who were diagnosed with CHC during August 2017 to May 2020 were enrolled in this observational study. All belonged to genotype 1; received DAA regimen comprising of sofosbuvir $400 \mathrm{mg}$ and ledipasvir $90 \mathrm{mg}$ for 12 weeks with good drug compliance and no major adverse effects. All of them attained SVR at 12 weeks after completing treatment. This study among adolescent survivors of childhood leukaemia with chronic hepatitis $\mathrm{C}$ genotype 1, augments data regarding efficacy of a 12 weeks DAA regimen comprising of sofosbuvir $400 \mathrm{mg}$ and ledipasvir $90 \mathrm{mg}$ in the attainment of SVR at 12 weeks after completing treatment.
\end{abstract}

Keywords: Chronic hepatitis C, DAA, SVR

\section{INTRODUCTION}

Children are an important target population for achieving WHO's global health sector strategy for elimination of HCV by $2030 .^{1}$ A recent modelling study has estimated viraemic prevalence for $\mathrm{HCV}$ in the paediatric population aged $0-18$ years to $0.13 \%$ (95\% uncertainty interval 0.08 $0.16)$, corresponding to 3.26 million $(2.07-3.90)$ children with HCV in 2018.

A higher prevalence of $\mathrm{HCV}$ is seen among children treated for malignancy, those with renal failure requiring hemodialysis and those who had undergone surgical procedures. $^{2}$

The European Medicines Agency (EMA) and the FDA approved the use of fixed-dose ledipasvir/sofosbuvir (LDV/SOF) $90 \mathrm{mg} / 400 \mathrm{mg}$ once daily to treat adolescents [ages12-17 or weight $>35 \mathrm{~kg}$ ) with Chronic hepatitis $\mathrm{C}$ (CHC) with genotypes 1 and 4] in 2017. Sofosbuvir with ribavirin was also approved to treat adolescents with $\mathrm{CHC}$ with genotypes 2 and 3. There are ongoing trials for treatment with these agents for younger children. The recommendations (2018) from the Hepatology Committee 
of the European Society of Pediatric Gastroenterology, Hepatology, and Nutrition (ESPGHAN) on the use of Directly acting antivirals (DAA) in pediatric patients indicated positive efficacy and favourable safety profiles of the different combinations of DAAs. DAA therapy is recommended for all adolescents aged 12-17 years with $\mathrm{CHC}$ virus infection independent of treatment history and disease severity.

In children, SVR12 (sustained viral remission 12 weeks after completion of therapy) corresponds to definitive cure in $98-100 \%$ of cases. A high sustained virological remission, improved compliance due to the oral route of administration and lesser side effects have made these DAAs more promising for their use in children. ${ }^{3}$

There are limited epidemiological data on pediatric $\mathrm{CHC}$ from India. Nagral et al found $13.3 \%$ patients with thalassemia major tested positive for $\mathrm{HCV}$, of which onefourth were viremic. ${ }^{4}$ Further, there are only very limited published literature on the efficacy and safety of DAA in pediatric $\mathrm{CHC}$ from India. Studies from India have reported high prevalence of hepatitis $\mathrm{C}$ (6\%-25\%) infection in survivors of childhood cancers. ${ }^{5-7}$ However, there is no data on the sustained viral remission of DAA in the treatment of CHC among adolescent (12-17 years) survivors of childhood leukemia. We performed this retrospective analysis to study sustained viral remission (SVR) with DAA in the treatment of CHC among adolescent (12-17 years) survivors of childhood leukemia.

The aim of the study was to analyze the genotypic profile of hepatitis $C$ virus and adverse effects of the DAA in this group of adolescents (12-17 years).

\section{CASE SERIES}

The case records of adolescent (12-17 years) survivors of childhood leukaemia diagnosed with $\mathrm{CHC}$ during August 2017 to May 2020 at the pediatric gastroenterology services, department of pediatrics, SAT Hospital and department of gastroenterology, Government Medical College, Thiruvananthapuram were analyzed after the study was approved by the Institutional Ethics Committee (No.06/20/2020/MCT/13.11.2020). Chronic hepatitis C was diagnosed on the basis of Anti-HCV positivity confirmed with HCV RNA PCR positivity and genotyping to decide on DAA regimen. Patients with compensated or decompensated cirrhosis, treatment experienced, Hepatocellular carcinoma (HCC), renal failure (serum creatinine $>1.5 \mathrm{mg} / \mathrm{dl}$ ), co-infection with hepatitis B virus and/or HIV, significant cardiovascular, pulmonary, or neurological disease, malabsorption syndrome that could interfere with absorption of orally administered DAA and patients with history of solid organ or bone marrow transplantation were excluded.

All patients underwent clinical examination and were evaluated by Complete blood count (CBC), Liver function test (LFT), Renal function test (RFT), Thyroid stimulating hormone (TSH), and Serum ferritin levels. Other investigations included HBsAg status, HIV ELISA, abdominal ultrasonography (for evidence of cirrhosis and for the presence of collaterals) and transient elastography. Liver stiffness measurement more than $12.5 \mathrm{kPa}$ was taken as cut-off for the diagnosis of cirrhosis (Metavir F4). All adolescent children with $\mathrm{CHC}$ received the appropriate DAA regimen based on the genotype.

\section{Procedure}

Fixed-dose combination of ledipasvir/sofosbuvir (LDV/SOF) $90 \mathrm{mg} / 400 \mathrm{mg}$ and sofosbuvir with ribavirin was recommended once daily to treat adolescents (age 1217 or weight $>35 \mathrm{~kg}$ ) with $\mathrm{CHC}$ with genotypes 1 and 4) and genotypes 2 and 3 respectively. The response to treatment was assessed by documenting HCV viral load 12 weeks after stopping treatment. SVR is defined as undetectable HCV RNA 12 weeks after completion of treatment with DAAs. All adverse events experienced during, on completion and on follow-up of study treatment were noted.

\section{Outcomes}

During the study period from August 2017 to May 2020, total 5 adolescent (12-17 years) survivors of childhood leukemia were diagnosed with $\mathrm{CHC}$. All of them had received multiple blood transfusions during chemotherapy for leukemia and there was no family history of $\mathrm{CHC}$. The median age of the patients was 14.4 years (range 12-16) with a male female ratio of $2: 3$. The patients were detected to have base line viral load ranging from 456890 to $5317890 \mathrm{IU} / \mathrm{ml}$. Genotype 1 was seen in $100 \%$ patients. Since HCV genotype was 1 , all of them were started on Ledipasvir and Sofosbuvir (LDV/SOF) combination regimen (LDV/SOF) $90 \mathrm{mg} / 400 \mathrm{mg}$ once daily. All 5 patients on LDV/SOF were treatment naive and $100 \%$ attained sustained viral response 12 weeks at the end of treatment with good drug compliance and no major adverse effects.

The mean SGPT value prior to treatment was $70.2 \mathrm{IU} / 1$ and post treatment was $41.2 \mathrm{IU} / \mathrm{l}$. Our patients had only mild derangement of liver functions due to early detection of raising viral load through periodic screening and none of them had evidence of liver cell failure or cirrhosis upon diagnosis. All children had hepatomegaly and 3 of them had fatty liver sonologically. The mean liver stiffness by transient elastography was $5.7 \mathrm{kPa}$.

\section{DISCUSSION}

Three studies published in the last 2 decades from India highlight the high prevalence of hepatitis $\mathrm{C}$ infection (6$25 \%$ ) in our childhood cancer survivors. Blood product transfusion was major risk factor for transmission although there were likely to be other factors involved. Despite effective donor screening programs, a significant proportion of patients receiving regular blood transfusion 
are HCV positive. There is no vaccination to protect against contracting $\mathrm{HCV}$. Molecular testing for $\mathrm{HCV}$ RNA utilizing nucleic acid amplification technology (NAT) is the most sensitive assay and narrows down the window period to as short as 4 days. Rigorous testing of donated blood, standardization of laboratory screening procedures and implementation of NAT is required to achieve dramatic reductions in transfusion transmitted $\mathrm{HCV} .{ }^{5-7}$ Our study adds to the effectiveness of (LDV/SOF) combination regimen in the management chronic hepatitis C genotype 1 among adolescent children who are survivors of childhood leukaemia as demonstrated by attainment of $100 \%$ SVR.

Various other studies on the efficacy of DAA in the treatment of chronic hepatitis $\mathrm{C}$ in children from India have also documented the efficacy of DAA as evidenced by SVR rate varying from $89 \%$ to $100 \%$ (Table 1). In majority of these studies, the study population included a blend of cirrhotics and non-cirrhotics as well as both treatment naive and treatment experienced children unlike our series which included treatment naive and noncirrhotic only. ${ }^{8-11}$ If screening is positive, early testing of viral load and genotyping will help, offered by a good SVR rates varying from therapy before the onset of liver disease. DAAs should be considered as a first-line therapy in either naive or treatment experienced.

With the implementation of National Viral Hepatitis Control Program (NVHCP) in 2018 in India, access to generic combinations of DAAs is now free and this will help in a big way to attain the ambitious targets set by the WHO to eliminate HCV infection as a public health problem by 2030 . The limitation of the study included the small sample size and the retrospective study design.

Table 1: Comparison of our data with other studies from India.

\begin{tabular}{|c|c|c|c|c|c|c|}
\hline $\begin{array}{l}\text { Series and patient } \\
\text { characteristics }\end{array}$ & $\begin{array}{l}\text { Age } \\
\text { (years) }\end{array}$ & $\begin{array}{l}\text { Sample } \\
\text { size }\end{array}$ & Genotype & $\begin{array}{l}\text { Treatment } \\
\text { regimen }\end{array}$ & $\begin{array}{l}\text { Treatment } \\
\text { duration }\end{array}$ & $\begin{array}{l}\text { *SVR12 } \\
(\%)\end{array}$ \\
\hline $\begin{array}{l}\text { Nagral et al (2018) } \\
\text { Mumbai: } \\
\text { Thalassemics, cirrhotics and non- } \\
\text { cirrhotics } \\
\text { Both treatment naive and } \\
\text { treatment experienced }\end{array}$ & $12-17$ & 18 & 1,3 & $\begin{array}{l}\text { GT 1- sofosbuvir + } \\
\text { ledipasvir } \\
\text { GT 3- sofosbuvir + } \\
\text { daclatasvir } \\
\text { Cirrhotics received } \\
\text { ribavarin in addition }\end{array}$ & 12 weeks $^{\#}$ & 89 \\
\hline $\begin{array}{l}\text { Dhiman et al (2019) } \\
\text { Chandigarh: } \\
\text { Cirrhotics and non-cirrhotics } \\
\text { Both treatment naive and } \\
\text { treatment experienced }\end{array}$ & $12-17$ & 55 & $1,3,4,5$ & $\begin{array}{l}\text { GT 1,4,5- } \\
\text { sofosbuvir+ } \\
\text { ledipasvir } \\
\text { GT 3- sofosbuvir + } \\
\text { daclatasvir } \\
\text { cirrhotics received } \\
\text { ribavarin inaddition }\end{array}$ & 12 weeks $^{\#}$ & 98.2 \\
\hline $\begin{array}{l}\text { Padhi et al (2018), } \\
\text { Jaipur } \\
\text { Thalassemics } \\
\text { Treatment naive and non-cirrhotic }\end{array}$ & $5-14$ & 14 & 3 & $\begin{array}{l}\text { Sofosbuvir + } \\
\text { daclatasvir }\end{array}$ & 12 weeks & 100 \\
\hline $\begin{array}{l}\text { Sivasankaran et al (2018), } \\
\text { Chennai } \\
\text { Thalassemics } \\
\text { Both treatment naive and } \\
\text { treatment experienced }\end{array}$ & 2- 18 & 18 & $1(84 \%)$ & $\begin{array}{l}\text { Sofosbuvir + } \\
\text { ledipasvir }\end{array}$ & 12 weeks & 100 \\
\hline $\begin{array}{l}\text { Our series (2021), } \\
\text { Thiruvananthapuram } \\
\text { Adolescent survivors of childhood } \\
\text { leukemia } \\
\text { Treatment naive and non-cirrhotic }\end{array}$ & $12-17$ & 05 & 1 & $\begin{array}{l}\text { Sofosbuvir + } \\
\text { ledipasvir }\end{array}$ & 12 weeks & 100 \\
\hline
\end{tabular}

Note: *SVR- Sustained viral remission 12 weeks post-treatment, ${ }^{\#}$ Cirrhotics for 24 weeks.

\section{CONCLUSION}

This is the first report from India on the efficacy of DAA in adolescent (12-17 years) survivors of childhood leukaemia diagnosed with $\mathrm{CHC}$, genotype 1. It is clear that ledipasvir with sofosbuvir is very effective with $100 \%$ SVR and safe in this patient population who are treatment naive and non-cirrhotic. We planned to follow up our 
cohort to document sustained virological response over the next few years.

\section{ACKNOWLEDGEMENTS}

Authors would like to thank other faculty and residents in their departments for their support during the study.

Funding: No funding sources

Conflict of interest: None declared

Ethical approval: The study was approved by the Institutional Ethics Committee No.06/20/2020/MCT/ 13.11.2020

\section{REFERENCES}

1. Indolfi G, Easterbrook P, Dusheiko G, Sayed MH, Jonas MM, Thorne $\mathrm{C}$, et al. Hepatitis $\mathrm{C}$ virus infection in children and adolescents. Lancet Gastroenterol Hepatol. 2019;4(6):477-87.

2. Schmelzer J, Dugan E, Blach S, Coleman S, Cai Z, Paola M, et al. Global prevalence of hepatitis $\mathrm{C}$ virus in children in 2018: a modelling study. Lancet Gastroenterol Hepatol. 2020;5(4):374-92.

3. Indolfi G, Hierro L, Dezsofi A, Jahnel J, Debray D, Hadzic N, et al. Treatment of Chronic Hepatitis C Virus Infection in Children: A Position Paper by the Hepatology Committee of European Society of Paediatric Gastroenterology, Hepatology and Nutrition. J Pediatr Gastroenterol Nutr. 2018;66(3):505-15.

4. Nagral A, Sawant S, Nagral N, Parikh P, Malde P, Merchant R. Generic Direct Acting Antivirals in Treatment of Chronic Hepatitis $\mathrm{C}$ Infection in Patients of Thalassemia Major. J Clin Exp Hepatol. 2017;7(3):172-8.
5. Kurkure P, Achrekar S, Dalvi N, Goswami S. Childhood cancer survivors-living beyond cure. Indian J Pediatr. 2003;70:825-8.

6. Rajendranath R, Veeraiah S, Ramesh A, Sagar TG. Late effects of treatment in survivors of childhood cancer from a tertiary cancer center in South India. South Asian J Cancer. 2014;3(1):60-5.

7. Seth R, Singh A, Guru V, Chawla B, Pathy S, Sapra S. Long-term follow-up of retinoblastoma survivors: Experience from India. South Asian $\mathbf{J}$ Cancer. 2017;6(4):176-9.

8. Nagral A, Jhaveri A, Sawant S, Parikh NS, Nagral N, Merchant R, et al. Treatment of Chronic Hepatitis C Infection with Direct Acting Antivirals in Adolescents with Thalassemia Major. Indian J Pediatr. 2019;86(2):148-53.

9. Dhiman RK, Grover GS, Premkumar M, Taneja S, Duseja A, Rathi $\mathrm{S}$, et al. Direct-acting antiviral Therapy Is Safe and Effective in Pediatric Chronic Hepatitis C: J Pediatr Gastroenterol Nutr. 2019;68(1):74-80.

10. Padhi S, Maharshi S, Gupta GK, Garg K, Nijhawan S. Efficacy and Safety of Direct Acting Antiviral Therapy for Chronic Hepatitis C in Thalassemic Children. J Pediatr Hematol Oncol. 2018;40(7):5114.

11. Sivasankaran M, Venkatadesikalu M, Mythili V, Sankaranarayanan S, Jayaraman D, Patel S, et al. Ushering a New Era in the Management of Hepatitis $\mathrm{C}$ in Children with Hematological Disorders. Indian J Hematol Blood Transfus. 2018; 34(4):739-41.

Cite this article as: Sobhan PKN, Sarojam B. Sustained viral remission with directly acting antivirals in the treatment of chronic hepatitis $\mathrm{C}$ among adolescent (1217 years) survivors of childhood leukemia. Int $\mathrm{J}$ Contemp Pediatr 2021;8:1735-8. 